\title{
References:
}

1. United States Dastance Learning Association. Retrieved from: htpp://www.usdla.org (accessed 15 April 2020).

2. Kontseptsiia rozvytku osvity Ukrainy na period 2015-2025 rr. Retrieved from: http://www.irf.ua/knowledgebase/news/koncepciya_rozvytku_osvity_na_period_2015 2025rr/ (accessed 17 April 2020).

3. Dejneka, L. (ed.) (2019). Metodyka vykladannja inozemnoji movy v pochatkovij shkoli [Methods of teaching a foreign language in primary school]. Skhidnojevrop. nac. un-t im. Lesi Ukrajinky, Biblioteka. Lucjk, 159 nazv. (in Ukrainian)

4. Retrieved from: https://classroom.google.com/u/0/c/NTQ1NjkxMTI3NTda (accessed 15 April 2020).

5. Retrieved from: https://docs.google.com/forms/d/1GI1NDdnvtzOcEaw6Ppxg ATMxFS6FWinBCQO4N-nMd_Y/edit\#responses (accessed 15 April 2020).

\section{USING OF INTELLECTUAL MAPS AT THE LESSONS OF MATHEMATICS AT GENERAL SECONDARY EDUCATION INSTITUTIONS}

\section{Alina Klimishyna ${ }^{1}$ \\ DOI: https://doi.org/10.30525/978-9934-588-52-5-6}

An important task of every teacher is to teach a child to think. Every year, as part of the reform and modernization of the educational system, the amount of educational material increases and it is clear that it is becoming increasingly difficult for pupils to remember and operate with such a large amount of information. Therefore, when explaining new material to the teacher, it is necessary to develop in pupils the ability to analyze, synthesize, evaluate, summarize, as well as highlight the main and related concepts.

It is worth noting that scientists who have studied the problems of neurophysiology have made an important discovery about the functional asymmetry of the hemispheres of the human brain, which can not be ignored during training. It is proved that the right hemisphere is «responsible» for figurative thinking, for holistic perception, for the perception of spatial forms, and the left - for language, logic, work with signs. In the vast majority of people, the right hemisphere is included in the work first when acquainted with new information. Therefore, for the successful development of knowledge it is advisable to strengthen the visual component of the material, which is presented as a counterweight (in some cases) or a necessary

\footnotetext{
${ }^{1}$ General Education School of I-III degrees № 1, Ivaniv, Ukraine
} 
«support» of the abstract-logical component. From the standpoint of this discovery, most scientists note that in training it is necessary to give sufficient «food» to the right hemisphere of the child. Therefore, methods that use the child's figurative thinking will be in demand [1, p. 7].

Given the above, a very popular learning technology is mindmapping. This technology is quite convenient and allows you to effectively recover information, generate and capture new ideas, draw conclusions and establish links between them. The basis of mindmapping is mind maps, which were first mentioned in the famous book «The Mind Map Book» by Tony and Barry Buzan (Tony Buzan, Barry Buzan), published in 1993 [2]. The method of Buzan is directed at the development of the right hemisphere of the human brain [3, p. 68].

Quite often mental maps are also called intellectual maps, maps of mind, knowledge, memory, etc. English psychologist Tony Buzan defines a «mental map» as a scheme that visualizes certain information during human processing, a way of depicting the process of general systemic thinking using structural-logical schemes of radial organization. A memory card is implemented in the form of a diagram showing words, ideas, tasks, or other concepts connected by branches away from the central concept or idea. At the heart of this technique is the principle of «radial thinking», which refers to associative mental processes, the starting point or point of contact of which is the central object. With the help of maps compiled according to certain rules, you can create, visualize, structure and classify ideas and visually present quite complex concepts and large amounts of information [2].

Intellectual maps can be created on paper (the original way), or with the help of software. We present in the table examples of several fairly simple and easy to use web services designed to create intellectual maps (Table 1).

Give an example of the use of mindmapping technology in the study of mathematics in general secondary education institution. With the purpose to repeat and generalize the concepts, we elaborated the intellectual map on the topic «Derivative» for ten formers.

It should be noted that the created intellectual map was used by us to conduct a lecture-visualization on the topic: «Differential calculus of the function of one variable» for the students of the first course of specialty «Mathematics» Vinnytsia Mykhailo Kotsiubynskyi State Pedagogical University.

Fragments of the intellectual map are presented in Figures 1, 2, 3 (intellectual map created using the web service Mindomo, http://www.mindomo.com/). 


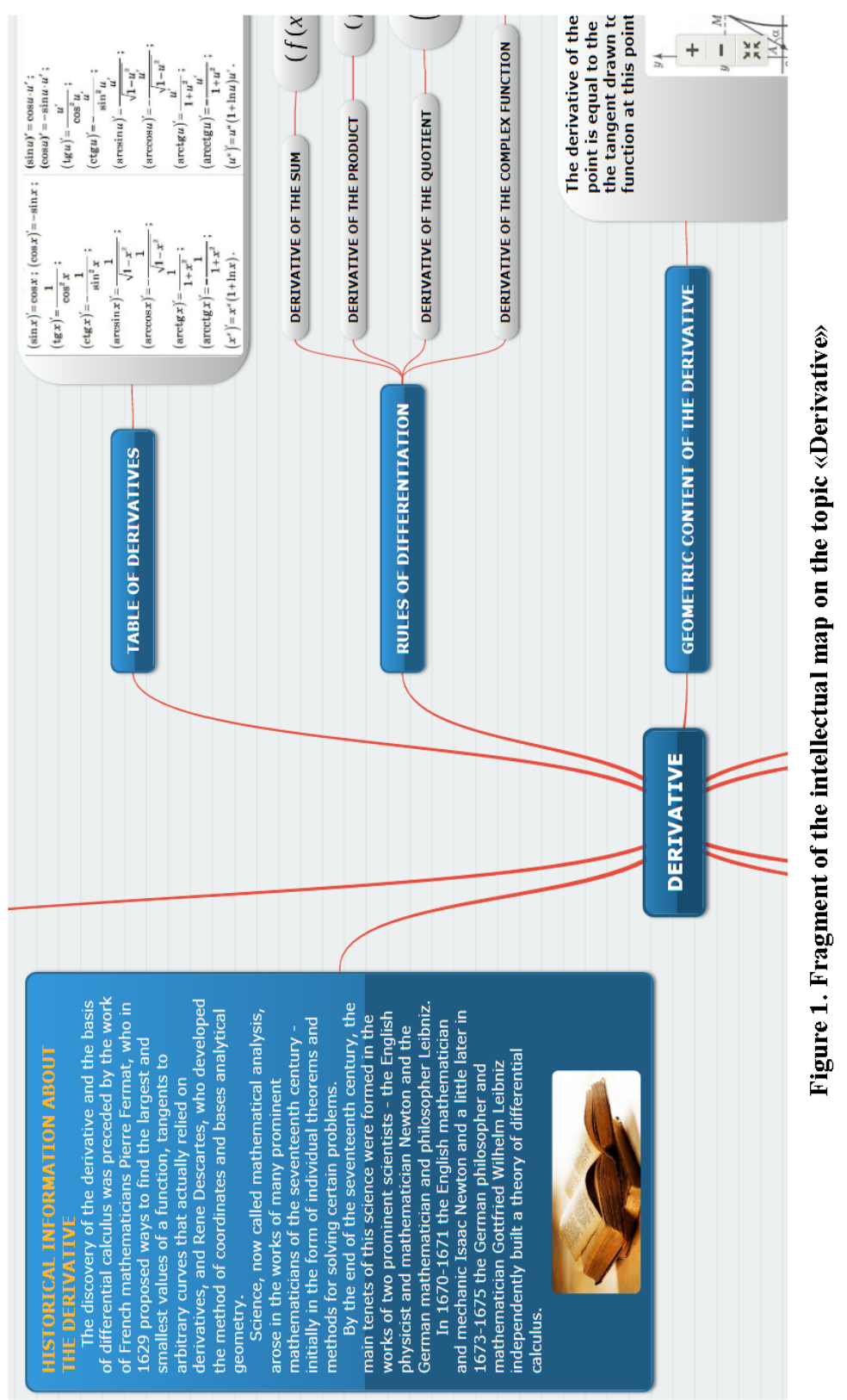




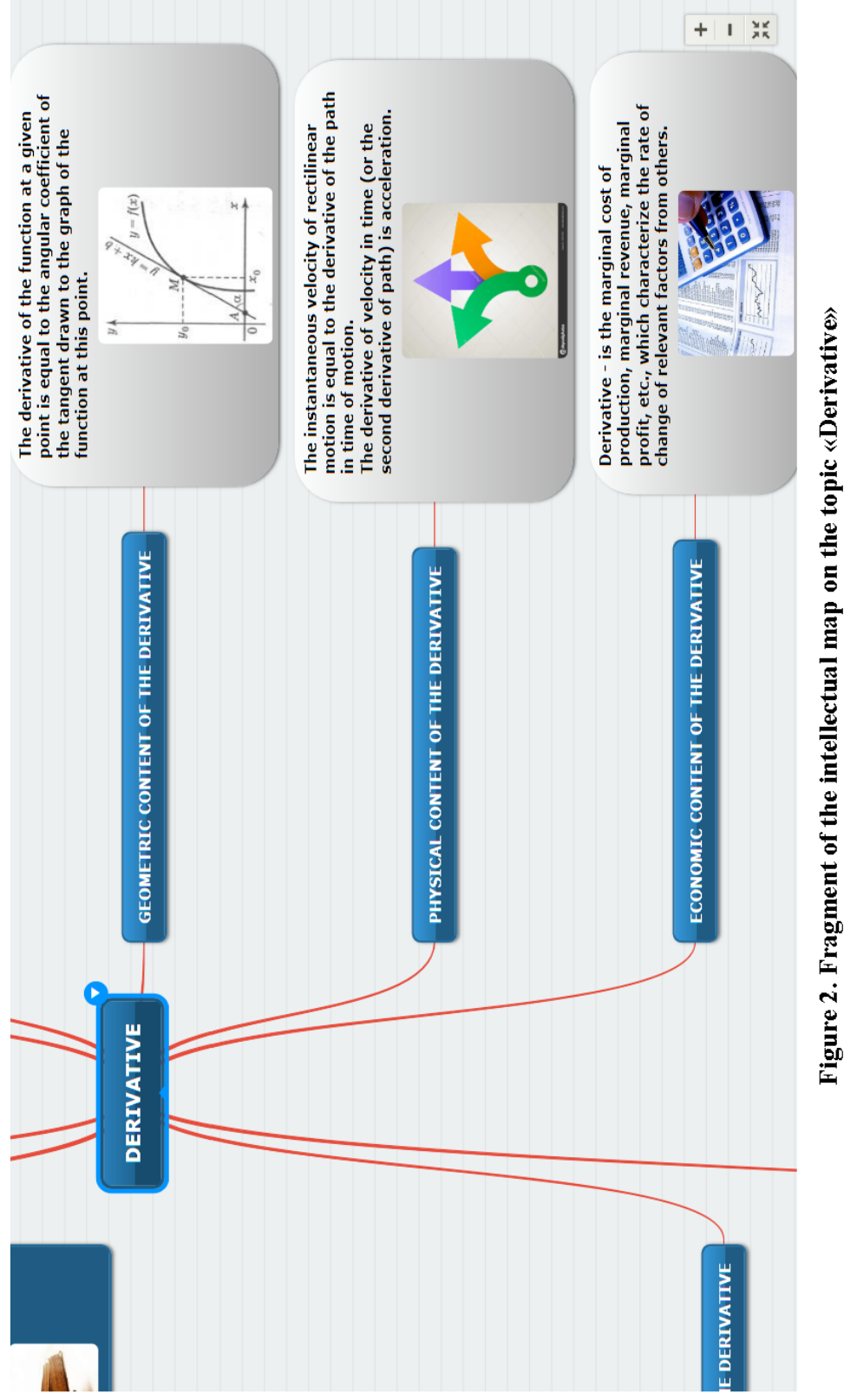




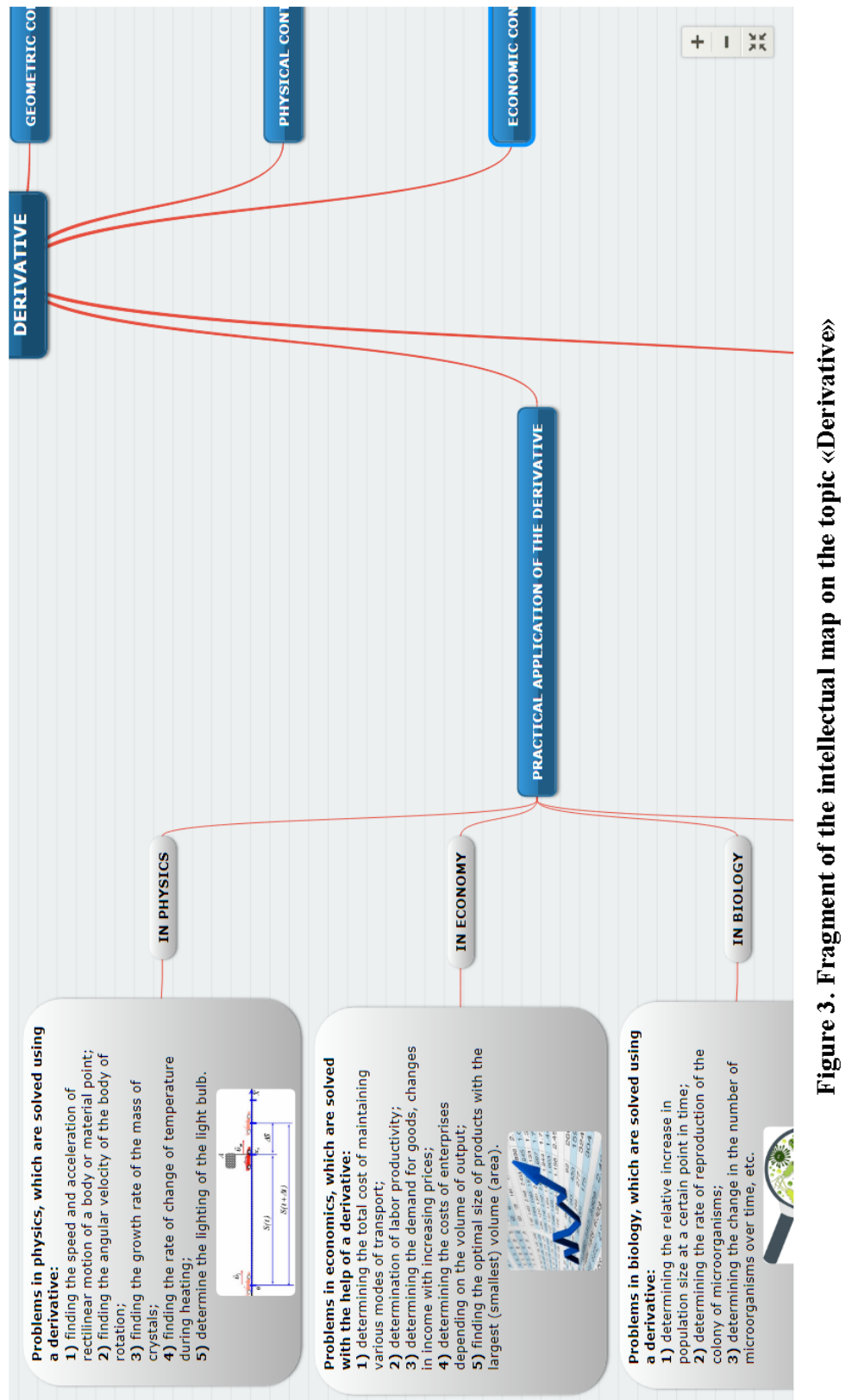


Types of web services for creating intellectual maps

\begin{tabular}{|c|c|}
\hline Web service, address & Main characteristics \\
\hline $\begin{array}{l}\text { Bubbl.us } \\
\text { https://bubbl.us/ }\end{array}$ & $\begin{array}{l}\text { The service is designed to create simple } \\
\text { intellectual maps. In the free version, } \\
\text { smart cards are filled only with text } \\
\text { information, and in the paid version, you } \\
\text { can also add images. } \\
\text { It is possible to work together on the } \\
\text { intellectual map. To do this, each user } \\
\text { only needs to create their own account. } \\
\text { English language interface. } \\
\text { Cyrillic is supported. } \\
\text { Registration required. }\end{array}$ \\
\hline $\begin{array}{l}\text { Mindomo } \\
\text { http://www.mindomo.com/ }\end{array}$ & $\begin{array}{l}\text { The service is designed to create bright } \\
\text { intellectual maps that contain images, } \\
\text { photos, videos, sound, links. } \\
\text { Advantages of the service: unlimited } \\
\text { number of simultaneous users; instant } \\
\text { changes are displayed to all users; } \\
\text { comments and voting opportunities; auto } \\
\text { storage; online and offline } \\
\text { synchronization. } \\
\text { English language interface. } \\
\text { Registration required. }\end{array}$ \\
\hline $\begin{array}{l}\text { Popplet } \\
\text { http://popplet.com/ }\end{array}$ & $\begin{array}{l}\text { The service is designed to create } \\
\text { multimedia intellectual maps that can } \\
\text { contain text, images, videos. Fragments of } \\
\text { the intellectual map can be highlighted in } \\
\text { different colors, resize, move. In addition, } \\
\text { you can change the scale of the intellectual } \\
\text { map: zoom in or out the desired elements. } \\
\text { It is possible to work together on the } \\
\text { intellectual map. } \\
\text { English language interface. } \\
\text { Registration required. }\end{array}$ \\
\hline $\begin{array}{l}\text { XMind } \\
\text { https://www.xmind.net }\end{array}$ & $\begin{array}{l}\text { The service is designed to create } \\
\text { intellectual maps. } \\
\text { Large selection of intellectual map } \\
\text { design: different backgrounds, types of } \\
\text { lines, colors, tools, shapes, icons. } \\
\text { Several users can work on creating the } \\
\text { intellectual map. } \\
\text { English language interface. }\end{array}$ \\
\hline
\end{tabular}


(End of table 1)

\begin{tabular}{|l|l|}
\hline \multicolumn{1}{|c|}{ Web service, address } & \multicolumn{1}{c|}{ Main characteristics } \\
\hline $\begin{array}{l}\text { Coggle } \\
\text { https://coggle.it }\end{array}$ & $\begin{array}{l}\text { The service is designed to create } \\
\text { intellectual maps with any number of } \\
\text { branches, and you can change their } \\
\text { position and color. } \\
\text { It is possible to work together to create } \\
\text { an intellectual map. } \\
\text { You need a Gmai account to use it. } \\
\text { English language interface. }\end{array}$ \\
\hline $\begin{array}{l}\text { SpiderScribe } \\
\text { http://www.spiderscribe.net/ }\end{array}$ & $\begin{array}{l}\text { The service is designed to create } \\
\text { intellectual maps to which you can add } \\
\text { text, images, calendar events and } \\
\text { geographical location. }\end{array}$ \\
& $\begin{array}{l}\text { It is possible to work together to create } \\
\text { an intellectual map. } \\
\text { English language interface. } \\
\text { Registration required. }\end{array}$ \\
\hline
\end{tabular}

Thus, using of intellectual maps in the educational process of general secondary education institution allows teachers:

- to interest pupils and form motivation to study;

- improve pupils' perception and memorization of new material;

- induce pupils to solve a problem;

- organize pupils' work in class, etc.

\section{References:}

1. Bezuhlyi, D. (2014). Pryiomy vizualnoho podannia navchalnoi informatsii [Techniques of visual presentation of educational information]. Fizyko-matematychna osvita, vol. 2(3), pp. 7-15.

2. Buzan, T. (1993). The Mind Map Book: how to use radiant thinking to maximize your Brain's untapped potential. London: BBC Boks.

3. Cherhinets, I. (2015). Maindmeppinh - zruchnyi i efektyvnyi sposib orhanizatsii tvorchoho myslennia uchnia [Mindmapping is a convenient and effective way to organize a pupil's creative thinking]. Aktualni pytannia pryrodnycho-matematychnoi osvity, no. 5-6, pp. 66-71. 